\title{
Misiunea prin argument: Jean-Luc Marion și apologia creștină
}

Nicolae TURCAN*

Abstract: This paper discusses the Jean-Luc Marion's view on reason and faith, and on the necessity of the argument in contemporary apologetics. In Marion's opinion, the mission of a Christian intellectual in the postmodern world is to transform kerygma in arguments for the unbelievers. Exercising a postmetaphysical apologia, Marion's argumentation can be a model for the Christian mission today.

Keywords: reason and faith, Revelation, postmodernity, kerigma, apologetics, mission.

\section{Misiunea în postmodernitate}

Misiunea astăzi înseamnă misiunea în postmodernitate, adică

* Doctorand, Universitatea 1 Decembrie 1918 din Alba Iulia; lector universitar dr., Universitatea Babeș-Bolyai, Facultatea de Teologie Ortodoxă, Cluj-Napoca, România. 
a face să se audă chemarea iubirii lui Dumnezeu în urechile surde ale nihilismului contemporan. Fragmentarismul, diferența, refuzul tradiției, noua media, accesul fără precedent la cultură, toate acestea obligă pe misionarul creștin să exerseze propovăduirea credinței cu inteligenţă și cu argumente'. Exerciţiul apologetic își redobândește importanța într-o lume care nu mai crede în moștenirea Tradiției, ci doar în hermeneutici multiple, infinite, o lume pentru care forța argumentelor poate face diferența. Desigur, aceasta nu înseamnă depășirea paradoxului în care argumentul însuși se află și care trebuie semnalat: pe de o parte, sfârşitul metafizicii reduce statutul argumentului rațional la nivelul celui care îl rostește, transformându-1 în argument subiectiv, cu pretenții limitate; pe de altă parte, nicio dezbatere, nici măcar aceea împotriva domniei raţiunii, nu poate renunţa la argument, acesta devenind singurul care poate înclina balanța adevărului. Paradoxul argumentului arată că oricât de slabă s-ar dori gândirea astăzi, ea își exersează critica chiar la adresa raţiunii tari, metafizice, tot în termeni de argumente. Prin urmare, misiunea însăşi trebuie să fie o misiune cu argumente, chiar dacă acest lucru nu poate fi absolutizat, de vreme ce nu reprezintă decât o parte a ei.

Cum arată apologia creștină în gândirea lui Jean-Luc Marion? Ce rol mai poate avea raţiunea astăzi pentru a susține credinţa? Acestea sunt întrebările care deschid orizontul discuției de față și la care vom încerca să răspundem.

\section{Rațiune și credință}

Marion susţine indiscutabil revenirea lui Dumnezeu în discursul academic ${ }^{2}$, fiind, prin aceasta, un apologet de ultimă

${ }^{1}$ Pentru o discuție mai amplă asupra postmodernismului și teologiei, vezi Nicolae Turcan, Postmodernism și teologie apofatică. O apologie în fața gândirii slabe, Florești, Cluj, Limes, 2014.

${ }^{2}$ Tamsin Jones, A Genealogy of Marion's Philosophy of Religion: Apparent Darkness, Indiana Series in the Philosophy of Religion, Bloomington \& Indianapolis, Indiana University Press, 2011, p. 154. 
generație. Situația rațională a lumii de astăzi, tributară nihilismului ,pe care trebuie să-1 suportăm”, poate fi definită pornind de la criza postmodernă a fundamentelor ${ }^{4}$, criză ce afectează și modul în care înțelegem raționalitatea. Nihilismul devaluează toate valorile înalte alte metafizicii - fiind un fel de „formă negativă” ${ }^{5}$ a ei - şi le aruncă în zădărnicie ${ }^{6}$. Marion numește această situație ,gradul zero al raționalității”, fiindcă potrivit lui Habermas, doar raționalitatea comunicațională, care se dobândește prin dezbatere și argument, prin negociere și contract, mai poate convinge ${ }^{7}$.

Chiar dacă acest model, care poate fi criticat el însuși ca totalitar, periclitează până la un punct gândirea creștină - care, nutrindu-se din Revelație, nu-și poate renega fundamentele -, nu e mai puțin adevărat că oferă în același timp și două avantaje: mai întâi, gândirea creștină este eliberată de orice totalitarism ideologic, deci liberă să vorbească în principiu, și, apoi, ea chiar trebuie s-o facă, fiind chemată să aducă argumente convingătoare, de vreme ce ,credința nu este un strigăt", deși poate fi un martiriu'. Apelul la argument pentru a convinge ține

${ }^{3}$ Jean-Luc Marion, Le croire pour le voir: réflexions diverses sur la rationalité de la révélation et l'irrationalité de quelques croyants, Communio, Paris, Éditions Parole et Silence, 2010, p. 35/34; trad. rom.: Despre raționalitatea Revelației și iraționalitatea credincioșilor, trad. de Maria-Cornelia Ică jr, Sibiu, Deisis, 2014. În continuare, pe tot parcursul acestui studiu, paginația din edițiile românești va fi redată după cea din edițiile franceze, separată printr-o bară oblică.

${ }^{4}$ Idem, Le croire pour le voir, p. 32/31.

${ }^{5}$ Mikkel B. Tin, Saturated Phenomena: From Picture to Revelation in Jean-Luc Marion's Phenomenology, în „Filozofia”, 65, nr. 9, 2010, p. 875.

${ }^{6}$ Jean-Luc Marion, Le phénomène érotique, interviu de Laurence Devillairs, în „Études”, 399, nr. 11, 2003, pp. 483-494.

${ }^{7}$ Idem, La rigueur des choses. Entretiens avec Dan Arbib, Flammarion, Paris, 2012, pp. 38/37-38.

${ }^{8}$ Ibidem, p. 40.

${ }^{9}$ Cele două dimensiuni pot fi gândite împreună, așa cum se întâmplă într-o ultimă definire ortodoxă a apologeticii al cărei caracter este considerat „apologetic-mărturisitor”, Adrian Lemeni et al., Apologetica ortodoxă, vol. 
de esența teologiei înseși, de apologetică, obligând Biserica să facă mereu ,un efort de gândire, de argumentare și de persuasiune"10, idee care invalidează opinia că Marion n-ar susține Revelația cu argumente ci, considerând-o doar un donat, ar căuta să găsească un loc pentru meditaţia teologică asupra propriilor semnificaţi1 ${ }^{11}$. S-a obiectat, de asemenea, că, atâta timp cât Marion nu încearcă explicit și cu orice preț să convingă cititorul de adevărul Bisericii, apologetica lui rămâne implicită, nereușită și neconvingătoare ${ }^{12}$, dar din cele deja spuse putem vedea că nu este așa.

Pentru Marion, importanța argumentului în credință rămâne capitală: „,Fidelitatea faţă de o învăţătură nu înseamnă, nici aici, nici în altă parte, faptul de a o repeta, ci de a o gândi - de a o discuta argumentativ"13. Argumentele credinței dezvăluie un nou tip de raționalitate, ,mai puternică, [...] mai tainică și mai paradoxală (plus puissante, [...] plus secrète et paradoxale)", care nu coincide cu cea speculativă a metafizicii, nici cu cea calculatorie a științelor, ci aparține iubirii (charité) ${ }^{14}$. Această apartenență se transformă într-o datorie: inteligența este necesară pentru a vorbi în fața potenţialilor

1, Colecția Cursuri, Manuale și Compendii de Teologie Ortodoxă, București, Basilica, 2013, pp. 88-96. De asemenea, la fel se întâmplă cu dimensiunile rațională și spirituală în Dumitru Popescu, Apologetica rațional-duhovnicească a Ortodoxiei, Alexandria, Cartea ortodoxă, 2009.

${ }^{10}$ Jean-Luc Marion, La rigueur des choses. Entretiens avec Dan Arbib, p. 48.

${ }^{11}$ Opinie exprimată de Knut Alfsvåg, „Postmodern epistemology and the mission of the church”, în „Mission Studies”, 28, January 1 2011, p. 63. Am putea concede că este adevărată doar în contextul fenomenologiei lui Marion, dar existența textelor sale, care ar putea fi considerate teologice, infirmă această poziție.

${ }^{12}$ Aceasta este părerea lui Tamsin Jones și chiar dacă poate fi aplicată pentru anumite părți ale operei lui Marion, în principal pentru cele de fenomenologie, ea nu este corectă dacă citim textele lui cu conținut teologic. Vezi Tamsin Jones, A Genealogy of Marion's Philosophy of Religion, p. 153.

${ }^{13}$ Jean-Luc Marion, La rigueur des choses. Entretiens avec Dan Arbib, p. 51.

${ }^{14}$ Ibidem, p. 36. 
credincioși, fiind „o datorie a iubirii (un devoir de charité)"15.

Credinţa creștină nu cere o atitudine din care rațiunea să dispară, cu atât mai mult cu cât Logos-ul apare la începutul Evangheliei după Ioan, ceea ce arată că chiar atunci când rațiunea lumii este depăşită, raţiunea crucii, deși paradoxală, nu reneagă $\log o s-u^{16}$. Conceptul poate da mărturie de inefabilul divin, după cum o arată exemplele Sf. Iustin Martirul și Filosoful și cel al Sf. Maxim Mărturisitorul, căruia i s-au tăiat limba și mâna pentru a nu mai vorbi și a nu mai scrie ${ }^{17}$. Odată ce Infinitul cel incomprehensibil s-a întrupat, devenind trup asemenea nouă, om asemenea nouă, rațiunea finită îi poate servi drept expresie, fără a-1 face să-şi piardă incomprehensibilitatea ${ }^{18}$.

Dezbaterile intelectuale nu pot fi purtate în manieră nonintelectuală, prin simplul recurs la kerygma apostolică şi prin propovăduire, ci au nevoie de argumente, iar intelectualul botezat în Biserică trebuie să transforme kerygma în argumente ${ }^{19}$.

Cearta dintre rațiune și credință rămâne, după Marion, ideologică și incorectă, atâta timp cât întâlnim credințe implicate în raționalitatea științifică și rațiuni prezente în credința creștină ${ }^{20}$. Mai mult decât atât, istoria dezvoltării creștinismului a arătat că, prin încrederea în raţionalitatea lumii, încredere datorată unui Dumnezeu personal, creștinismul a contribuit la nașterea și dezvoltarea științelor ${ }^{21}$. Raționalitatea Revelației, deci a lui Dumnezeu, nu trebuie eliminată din creație, nici prin contradicție, în accese maniheiste, și nici în manieră gnostică, prin considerarea unei cunoașteri superioare

${ }^{15}$ Ibidem, p. 52.

${ }^{16}$ Idem, Le croire pour le voir, p. 18/14.

${ }^{17}$ Ibidem, pp. 18-19/15.

${ }^{18}$ Idem, The Formal Reason for the Infinite, în Graham Ward (ed.), „The Blackwell companion to postmodern theology", trad. de A.J. Wickens, Oxford; Malden, MA, Blackwell Publishers, 2001, pp. 405-406.

${ }^{19}$ Idem, Le croire pour le voir, p. 112/122.

${ }^{20}$ Ibidem, p. 17/13.

${ }^{21}$ Ibidem, p. 20/17. 
mântuitoare, inaccesibile în mod comun ${ }^{22}$. Rațiunea sa trebuie să adauge celorlalte rațiuni - științifice, poetice, politice, religioase, culturale - dimensiunea iubirii23 ${ }^{23}$. Chiar dacă această rațiune nu coincide cu cea a metafizicii (considerată speculativă), nici cu cea a ştiinței (rațiune calculatorie), raționalitatea iubirii este „mai puternică, dar mai tainică și paradoxală”’24.

\section{Credința}

Problema credinței iese în evidență ori de câte ori se pune întrebarea de ce credința noastră este atât de rea și de puțină. Un prim răspuns, întâlnit până la nivelul comun, este că ne scapă cunoașterea lucrurilor în care trebuie să credem, că ne lipsesc ideile clare și distincte care ne-ar putea da o știință pe baza căreia credința să fie edificată. Distingând între concepte și intuiţie, adică între ceea ce gândim și ceea ce vedem, Marion arată că, de fapt, ne lipsesc nu conceptele, atât de bine și de rafinat elaborate de teologie pe parcursul a peste două mii de ani, cât nu suntem în posesia intuiţiilor care ar putea să valideze anumite cunoștințe sau să invalideze altele. Știm destule despre Sfânta Treime, creație, existență, proprietăţi ale lui Dumnezeu, la fel cum avem cunoştințe suficiente despre realitatea istorică a lui Hristos, moartea şi învierea Sa etc. Dar nu avem manifestarea acestor cunoștințe, ne lipsește intuiția lor, de aceea credința vine să suplinească această lipsă și postulează adevărul lor ${ }^{25}$.

Acest argument atât de răspândit - de la oamenii comuni până la filosofi și teologi-nu este adevărat, susţine Marion, fiindcă el are structura unei blasfemii: el face din om decidentul ultim în privința existenței lui Dumnezeu, cu ajutorul rațiunii și al alegerii sale; de asemenea, este fals pentru că în aceste condiții Dumnezeu și Hristos se dovedesc fie

\footnotetext{
${ }^{22}$ Idem, La rigueur des choses. Entretiens avec Dan Arbib, pp. 36-37.

${ }^{23}$ Idem, Le croire pour le voir, p. 25/22.

${ }^{24}$ Ibidem, p. 36/35.

${ }^{25}$ Ibidem, pp. 195/215-216.
} 
„,neputincioși” (impuissants), incapabili să manifeste Revelaţia pe care au promis-o, fie ,judecători perverși”" (juges pervers) care îl expun pe om necredinței tocmai prin ascunderea lor. Or, argumentează Marion, credinţa nu este dată pentru a acoperi o penurie a intuiţiei, ci pentru a-i arăta excesul în raport cu puţinele noastre concepte ${ }^{26}$.

Exemplul este cel al episodului cu cei doi ucenici care, aflaţi pe drumul Emausului, îl întâlnesc pe Hristos, dar nu-L recunosc (Lc 24, 13-25). Lor nu le lipsește intuiția sensibilă a faptelor care se petrecuseră cu Hristos - minunile, judecata și moartea $\mathrm{Sa}$-, numai că aceasta nu este de ajuns pentru a le oferi credința. Ei nu-L recunosc fiindcă fenomenul care tocmai se întâmplă este inconceptibil, depășește orice așteptare, Răstignitul stând de vorbă cu ei ca orice om viu, pentru că înviase. Un asemenea eveniment nu poate fi captat de niciunul dintre conceptele de care ei dispuneau, chiar după ce Îi văzuseră minunile lui Hristos, Îi ascultaseră cuvintele care anunțaseră patimile și Învierea, Îi văzuseră schimbarea la față și, în general, trăiseră în orizontul minunii care ar fi trebuit să justifice și această ultimă și mare minune a Învierii. Ei vor înțelege însă nu când Hristos le va interpreta Scripturile în locurile care se refereau la El, ,ordonându-le conceptele”, ci când va binecuvânta și va frânge pâinea, oferindu-le un fenomen deplin, în care toate intuițiile se supun semnificațiilor lui Dumnezeu ${ }^{27}$.

În concluzie, susține fenomenologul francez, faptul că nu credem fiindcă nu avem intuiții pe măsura conceptelor noastre nu este adevărat, ci lipsa credinței se datorează unei incapacități de a primi un fenomen saturat, ale cărui semnificații nu sunt ușor de sesizat.

În această argumentare a lui Marion în favoarea credinței drept singura capabilă să sesizeze preaplinul Revelaţiei avem deja în lucru fenomenologia sa cu distincțiile dintre concept și intuiţie și cu accentul pus pe saturaţia pe care intuiţia o oferă în Revelația creștină. Fenomenologia oferă o bună paradigmă filosofică pentru teologie,

\footnotetext{
${ }^{26}$ Ibidem, p. 196/216.

${ }^{27}$ Ibidem, pp. 196-205/216-226.
} 
având un rol apologetic.

Concluzionând, putem afirma că, deși filosofia și teologia rămân, pentru Marion, distincte în metode și intenție, filosofia contribuie prin argumentele pe care le angajează la întărirea unor poziții teologice, acționând în mod apologetic. Am putea afirma că avem de-a face cu o nouă apologetică filosofică, o apologetică postmetafizică: păstrând distincțiile și eminența teologiei, aceasta nu se sfiește să apeleze la aparatul conceptual pentru a apăra credința Bisericii. Discursul teologului trebuie să presupună Revelaţia, progresul în sfințenie și depășirea metafizicii prin apelul la rugăciune, viață eclezială și comuniune de iubire cu Sfânta Treime. Acestea nu anulează posibilitatea apologiei, ci dimpotrivă, o hrănesc, fiindcă rolul teologului este și acela de a transforma kerigma apostolică în argumente pentru cei care încă nu cred.

\section{References:}

1. Alfsvåg, Knut, Postmodern epistemology and the mission of the church, în „Mission Studies”, 28, January 1 2011, pp. 54-70.

2. Jones, Tamsin, A Genealogy of Marion's Philosophy of Religion: Apparent Darkness, Indiana Series in the Philosophy of Religion, Bloomington \& Indianapolis, Indiana University Press, 2011.

3. Lemeni, Adrian; Ionescu, Răzvan; Mihalache, Sorin; Ioja, Cristinel, Apologetica ortodoxă, vol. 1, Colecția Cursuri, Manuale şi Compendii de Teologie Ortodoxă, București, Basilica, 2013.

4. Marion, Jean-Luc, The Formal Reason for the Infinite, în Graham Ward (ed.), „The Blackwell companion to postmodern theology”, traducere de A.J. Wickens, Oxford; Malden, MA, Blackwell Publishers, 2001, pp. 399-412.

5. Idem, La rigueur des choses. Entretiens avec Dan Arbib, Flammarion, Paris, 2012.

6. Idem, Le croire pour le voir: réflexions diverses sur la rationalité de la révélation et l'irrationalité de quelques croyants, Communio, Paris, Éditions Parole et Silence, 2010; trad. rom.: Despre 
raționalitatea Revelației și iraționalitatea credincioșilor, traducere de Maria-Cornelia Ică jr, Sibiu, Deisis, 2014.

7. Idem, Le phénomène érotique, interviu de Laurence Devillairs, în „Études”, 399, nr. 11, 2003, pp. 483-494; trad. rom.: Fenomenul erosului. Șase meditații, prezentare de Ioan I. Ică jr, traducere de Maria Cornelia Ică jr, Sibiu, Deisis, 2004.

8. Popescu, Dumitru, Apologetica rațional-duhovnicească a Ortodoxiei, Alexandria, Cartea ortodoxă, 2009.

9. Tin, Mikkel B., Saturated Phenomena: From Picture to Revelation in Jean-Luc Marion's Phenomenology, în „Filozofia”, 65, nr. 9, 2010, pp. 860-876.

10. Turcan, Nicolae, Postmodernism și teologie apofatică. $O$ apologie in fața gândirii slabe, Florești, Cluj, Limes, 2014. 
